\title{
Fiscal Regime Shifts in Portugal ${ }^{*}$
}

\author{
António Afonso, ${ }^{\#}$ Peter Claeys, ${ }^{ \pm}$and Ricardo M. Sousa ${ }^{\$}$
}

October 2009

\begin{abstract}
We estimate changes in fiscal policy regimes in Portugal with a Markov Switching regression of fiscal policy rules for the period 1978-2007, using a new dataset of fiscal quarterly series. We find evidence of a deficit bias, while repeated reversals of taxes making the budget procyclical. Economic booms have typically been used to relax tax pressure, especially during elections. One-off measures have been preferred over structural ones to contain the deficit during economic crises. The EU fiscal rules prompted temporary consolidation, but did not permanently change the budgeting process.
\end{abstract}

Keywords: fiscal regimes, Markov Switching, Portugal.

JEL classification: E62, E65, H11, H62.

\footnotetext{
* The opinions expressed herein are those of the authors and do not necessarily reflect those of the ECB or the Eurosystem. \# European Central Bank, Directorate General Economics, Kaiserstraße 29, D-60311 Frankfurt am Main, Germany. ISEG/TULisbon - Technical University of Lisbon, Department of Economics; UECE - Research Unit on Complexity and Economics; R. Miguel Lupi 20, 1249-078 Lisbon, Portugal. UECE is supported by FCT (Fundação para a Ciência e a Tecnologia, Portugal), financed by ERDF and Portuguese funds. Emails: antonio.afonso@ecb.europa.eu, aafonso@iseg.utl.pt.

\pm Universitat de Barcelona, Facultat de Econòmia i Empresa, Grup AQR IREA, Avinguda Diagonal, 690, E-08034 Barcelona, Spain. Email: peter.claeys@ub.edu.

\$ University of Minho, Department of Economics and Economic Policies Research Unit (NIPE), Campus of Gualtar, $4710-057$ Braga, Portugal; London School of Economics, Financial Markets Group, Houghton Street, London WC2 2AE, United Kingdom. Emails: rjsousa@eeg.uminho.pt; rjsousa@alumni.lse.ac.uk.
} 


\section{Contents}

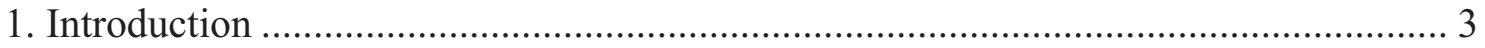

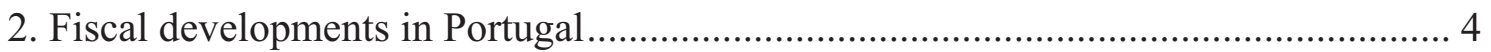

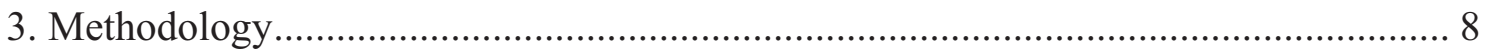

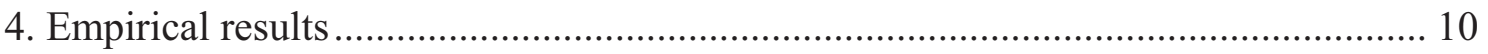

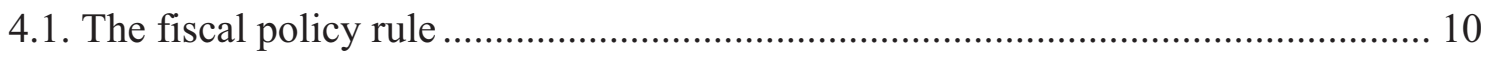

4.2. Procyclical policy changes and electoral cycles ................................................ 14

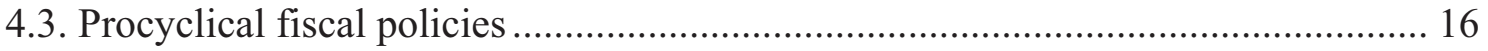

4.4. Cyclical asymmetry in the budget, and debt accumulation ................................... 19

4.5. Power dispersion and budget fragmentation: an interpretation ............................. 21

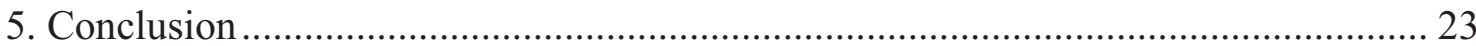

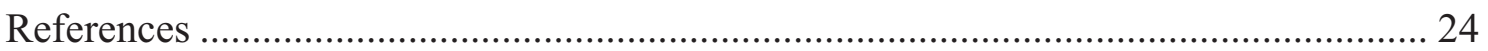

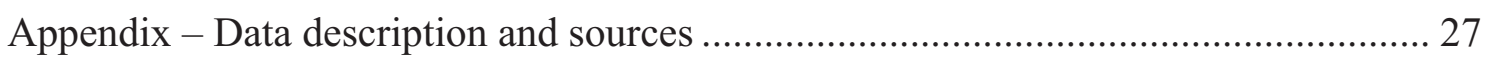




\section{Introduction}

The size of government is the outcome of a political conflict that reflects opposing views on the size of government and its means of financing. Budgetary outcomes are the consequence of the underlying political structure. A major overhaul of spending or the tax system is hard to implement in one electoral term. Governments usually decide on additional spending measures or introduce marginal changes to existing tax systems. Politicians thereby give in to calls for spending or tax changes after election into office, serving the interests of their constituencies. Moreover, economic fluctuations also entail responses in the budget in the short-term. Extra revenues flow in during an economic upswing. These automatic stabilisers also work on the spending side: in recession, unemployment benefits and social transfers start to rise. Hence, fiscal policy may switch its stance due to political and economic circumstances. Changes in fiscal policy are best understood by relating them to different regimes.

Portugal has a long record of persistently high and variable fiscal deficits. Since 1978 it did not exceed the 3\% of GDP threshold only in seven years. Indeed, Portugal was the first EU country to breach the rules of the Stability and Growth Pact (SGP) in 2002, and to become therefore subject to the Excessive Deficit Procedure (EDP). This situation occurred again in 2005 and 2009. To understand the failed attempts at fiscal consolidation requires a detailed analysis of budget processing in Portugal. In this paper, we apply Markov Switching (MS) techniques to track the time variation in the behaviour of fiscal policy. We look at the change in the reaction coefficients of a fiscal policy rule in which the government reacts to debt and the cycle. We test period by period the changes in the responses, and then relate the shifts in the fiscal regime with political and economic variables. We apply this to a new dataset of quarterly fiscal series - based on high frequency cash data - for Portugal over the period 1978-2007.

Our main finding is that budgetary problems have been chronic over the period 1978-2007. A lack of adjustment on the spending side has contributed to debt accumulation. Temporary gains from high economic growth and the reduction in debt service in the transition to EMU were missed as an opportunity for an overhaul in public finances. Erratic changes in tax policy have made fiscal policy procyclical. Economic booms have been typically used to relax tax pressure. One-off measures have been preferred over structural measures to contain the deficit during economic crises. The stricter surveillance of budget deficits under the SGP has only accentuated these problems. The EU fiscal rules forced temporary consolidation, but did not structurally 
change the budget process. The root cause of fiscal trouble is a lack of transparency on budget decisions, insufficient budget management, and a lax application of fiscal rules.

The remainder of the paper is organised as follows. In section two, we briefly review fiscal developments in Portugal and describe the dataset. In section three, we derive a fiscal policy rule, and present our Markov Switching methodology to characterise the time varying properties of fiscal policy. We interpret the different fiscal regimes in section four. We summarise our findings, and give some suggestions for fiscal reform in section five.

\section{Fiscal developments in Portugal}

We have built a quarterly dataset for Portugal from high frequency central government budget monthly cash data (Afonso and Sousa, 2009). These data are disseminated through the publications of the General Accounting Offices, the Ministry of Finance and the Bank of Portugal. The latest figures are also published in the IMF Special Data Dissemination Standard section. Figure 1 shows that the patterns of the cash based data budget series follow very closely the ones based on accrual based national accounts data for the general government provided by the European Commission (AMECO). ${ }^{1}$ The main reason is that central government is responsible for the bulk of the budget; local government spends just about $10 \%$ of the total budget.

Figure 1 shows the size of government, overall tax revenues and public debt since 1980. Fiscal developments in Portugal have to a large extent been determined by the integration in the EU and the EMU. Public spending has taken up an ever larger part of the economy. The size of government went up from 23.5 per cent of GDP in the 1970s to 35.8 per cent in the 1990s. Large part of this expansion was a catch up process with other EU countries. Recent trends in spending have been less reassuring. Under pressure of the Maastricht criteria, EU countries started curbing down public expenditure since the mid-1990s. In contrast, primary spending continued to rise and reached an average of 42.7 per cent between 2000 and 2008. Government revenues have been trending upward over the entire sample, but did not keep pace with the rise in government spending. As a consequence, Portugal has a record of persistent fiscal deficits since 1978. Only in seven years did the general government budget deficit not exceed $3 \%$. As a result of these continued budget deficits, government debt rose quickly

1 A detailed description is provided in the Appendix. 
in the early eighties, then stabilised around $60 \%$ of GDP, but has drifted upward again since 1999.

Figure 1 - Quarterly versus annual based fiscal data.

$1 \mathrm{a}$
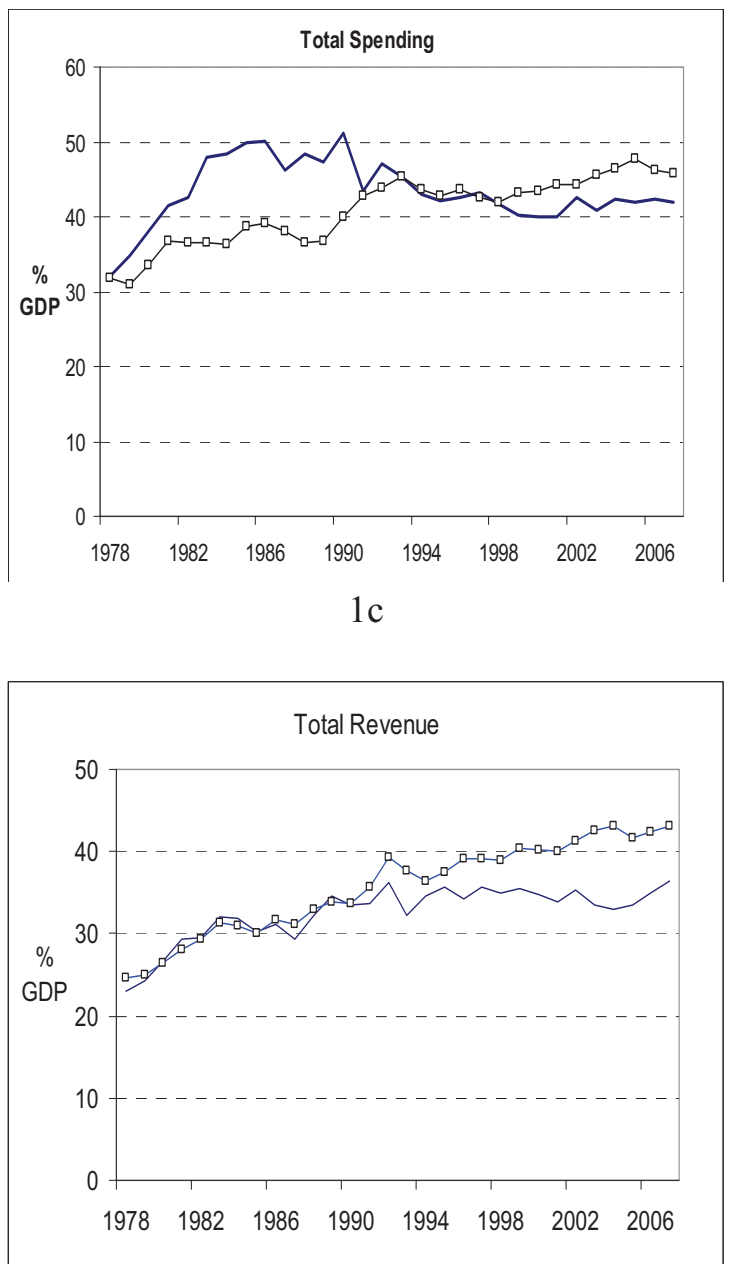

$1 \mathrm{~b}$
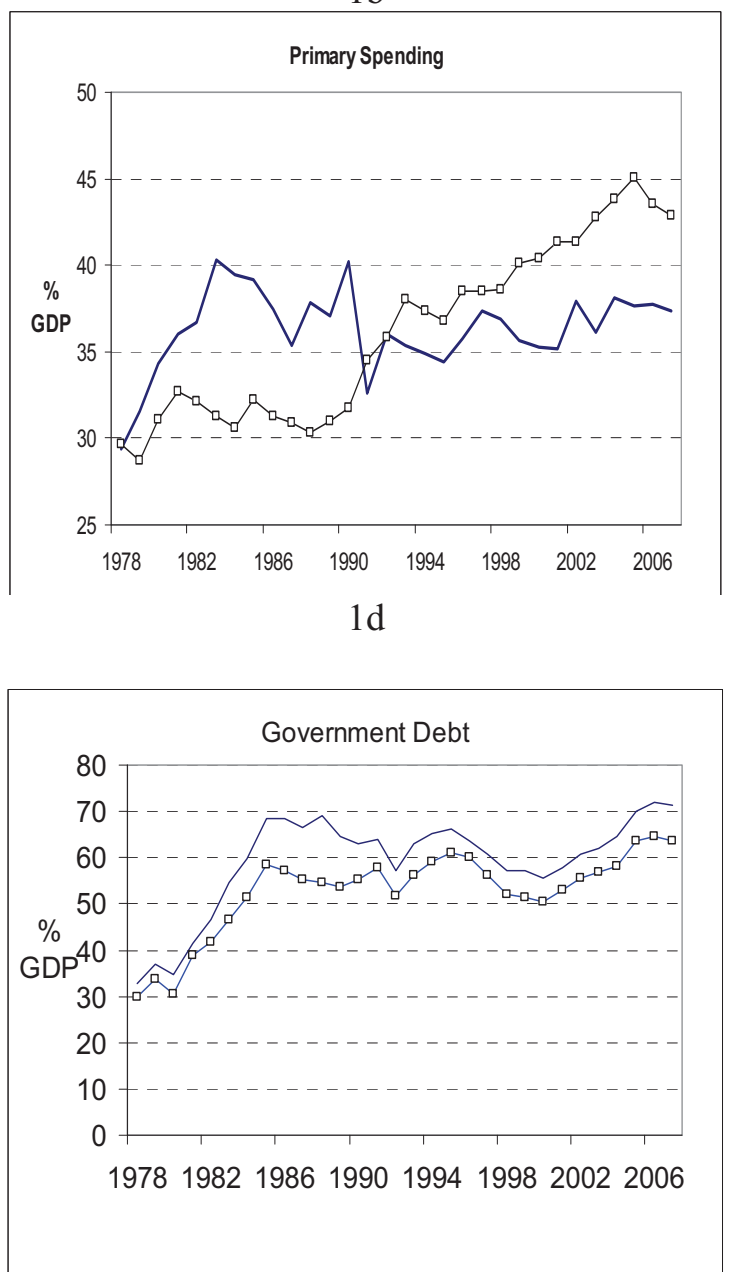

Note: ---- quarterly data - $\square-$ AMECO data; all variables are in percentage of GDP, sample period is 1978:1-2007:4.

Changes in the fiscal stance are also driven by cyclical fluctuations in the shortterm. High economic growth boosts tax revenues and diminishes spending on unemployment benefits or social transfers. At high levels of debt, changes in inflation and interest rates also have an important impact on debt service. A good summary indicator to capture both the long-term trends and the short-term fluctuations in the fiscal stance is the debt stabilising surplus. This is the surplus that stabilises government debt, and depends on the level of interest rates as well as on economic growth. The change over time in debt $b_{t}$ is given by the current primary surplus $s_{t}$, which is the difference between government revenues $t_{t}$ and primary government spending $g_{t}$, and the accumulation of interest payments on past fiscal imbalances. The latter part depends 
on the difference between the real interest rate $r_{t}$ and real economic growth $y_{t}$. If we express all data as a ratio to GDP, the government budget constraint (1) can be written as follows:

$$
b_{t} \equiv \frac{\left(1+r_{t}\right)}{\left(1+y_{t}\right)} b_{t-1}-s_{t} .
$$

If economic growth exceeds the additional interest payments, persistent deficits are still consistent with the stabilisation of debt: growth suffices to service debt. The debt ratio remains stable over time (that is, $b_{t}=b_{t-1}$ ) if the surplus equals

$$
\bar{s}_{t} \equiv \frac{\left(r_{t}-y_{t}\right)}{\left(1+y_{t}\right)} b_{t-1}
$$

Figure 2 plots the time path of this debt stabilising surplus $\bar{s}_{t}$, together with the output gap and the long-term real interest rate. High real interest rates and below average economic growth in the early eighties pushed this debt stabilising surplus up to $15 \%$ of GDP. The consequent decline is dominated by the gradual fall in interest rates. Since EU membership in 1986, long-term interest rates started to fall. Improved sovereign debt ratings further saved on the debt servicing costs. Weak economic growth in the first half of the nineties halted the fall in the debt stabilising surplus, which hovered around $5 \%$ of GDP. As long-term interest rates started to converge to EMU levels (by 1999, rates decreased by around 1650 basis points in total) and real economic growth received a corresponding boost between 1995 and 1999, the surplus fell further. It has been stable around $2 \%$ since then and it has been fluctuating much less.

Figure 2 shows how Portugal became the first country in the EU to breach the SGP 3\% deficit limit in 2001. The fall in economic growth in 2002 pushed up the debt stabilising surplus by nearly 4\%. On 5 November 2002, the EU Council ascertained an excessive deficit in Portugal and issued a recommendation requesting Portugal to bring the deficit back below 3\% by 2003 at the latest. An EU Council Decision of 11 May 2004 abrogated further steps in the EDP as measures taken in 2003 already indeed reduced the deficit below 3\%. Despite this quick consolidation, the deficit shot above the 3\% limit again in 2004, and a second EDP was initiated in 2005. The European Commission recommended a gradual reduction of the cyclically-adjusted deficit, 
excluding one-off and other temporary measures, by 1.5\% of GDP in 2006, and at least $0.75 \%$ of GDP in the following years. This deadline was extended to 2008. Portugal did not adjust the budget in a permanent way, and in October 2009, a new EDP was announced, also in the aftermath of the 2008-2009 global economic crises.

Figure 2 - Debt stabilising primary surplus.

$2 \mathrm{a}$

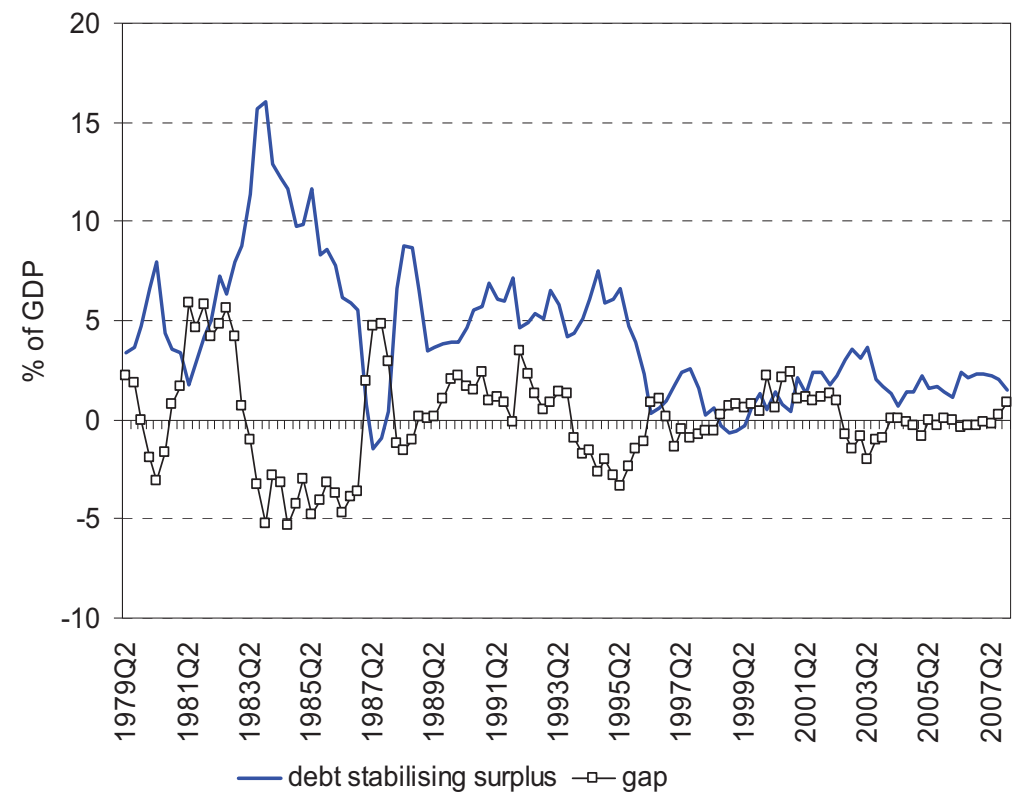

$2 \mathrm{~b}$

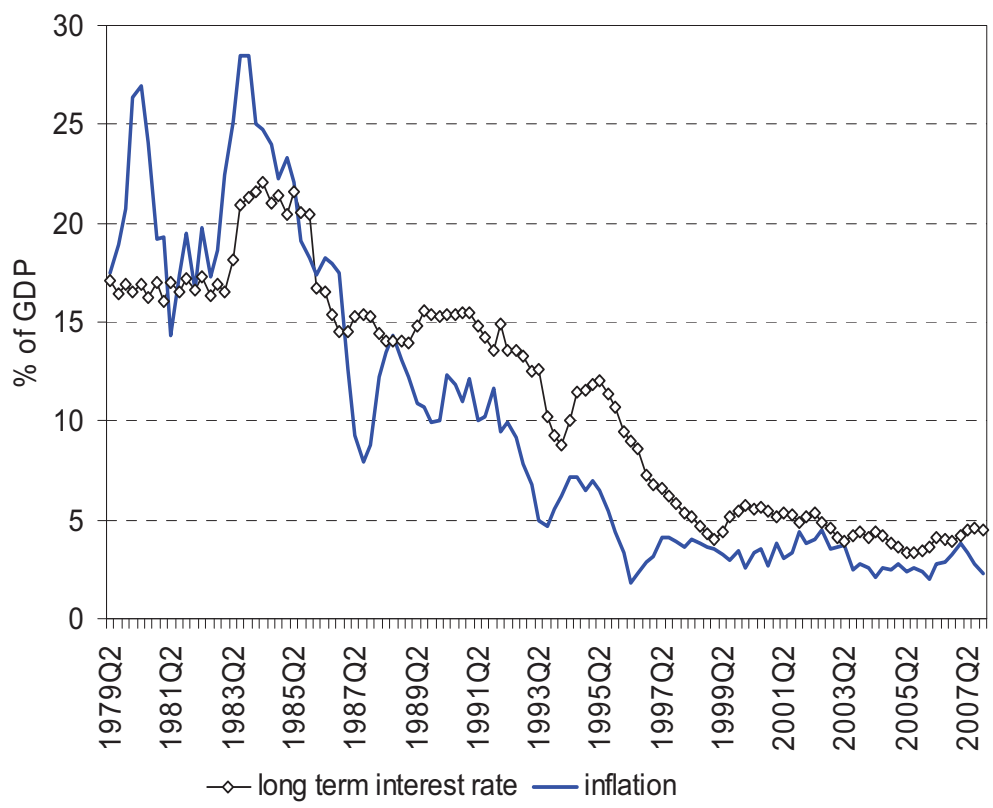

Source: authors' calculations. 


\section{Methodology}

We summarize the behaviour of fiscal policy with a reaction function that describes how a fiscal indicator changes in response to government debt and to the business cycle. Assume the government has some long-term target fiscal target $f^{*}$. It moreover decides to adjust this optimal target at time $t$ to keep under control the deviation of debt $b_{t}$ from some target level $b^{*}$. Given the structure of spending and taxation, the target will moreover fluctuate in response to expected deviations of output $y_{t}$ from some desired target output level $y^{*}$. This output response of the budget includes two components. In an economic boom, as output rises above its long-term level $\bar{y}$, unemployment benefits and transfer payments are reduced or tax receipts rise. In addition to these automatic stabilisers, the elasticity of these budget items with respect to output captures also includes systematic discretionary interventions of the government to steer the economy. The government may wish to lean against an economic crisis by cutting taxes or raising expenses. A fiscal reaction function for this time varying target surplus $\hat{f}_{t}$ can then be written as follows:

$$
\hat{f}_{t}=f^{*}+\gamma\left(y_{t}-y^{*}\right)+\theta\left(b_{t}-b^{*}\right) .
$$

Given that the budget process is typically characterized by long implementation lags the anticipated (endogenous) component of fiscal policy should be adequately represented by a simple feedback rule, in which the actual indicator $f_{t}$ only gradually adjusts to its target level:

$$
f_{t}=\rho f_{t-1}+(1-\rho) \hat{f}_{t}+v_{t} .
$$

Substitution of (3) into (4) gives the following non-linear relation between the fiscal instrument and public debt, and is the baseline fiscal rule we test:

$$
f_{t}=\rho f_{t-1}+(1-\rho)\left[\kappa+\gamma x_{t}+\theta b_{t}\right]+v_{t} .
$$


In (5), the output gap is given by $x_{t}=y_{t}-\bar{y}$. The constant term $\kappa=$ $f^{*}-\gamma\left(y^{*}-\bar{y}\right)-\theta b^{*}$ can be interpreted as a long-term fiscal indicator: it adjusts the target surplus for the deviation between the government's output target and long-term potential output, and for the government debt target. Deviations from the rule, which are captured by the residual term $v_{t}$, are discretionary changes in systematic fiscal policy.

We allow now the reaction coefficients in (5) to vary over time. A distinction has typically been made between policies that stabilise debt, or do not (Sims, 1994). These are either 'active' (non-Ricardian) or 'passive' (Ricardian) fiscal policies. ${ }^{2}$ Suppose that the fiscal instrument $f_{t}$ is the primary surplus-to-GDP ratio $s_{t}$. We moreover follow Favero and Monacelli (2005) and substitute debt $b_{t}$ for the debt stabilizing surplus $\bar{s}_{t}$ in (5). This non-linear fiscal rule implicitly controls for the timevarying effects of interest rates and growth on the debt service component of the deficit that are not under direct control of the government itself. In this case, fiscal policy is passive when the coefficient associated to the debt stabilising surplus $\bar{s}_{t}$ is not statistically different from one. In addition, the constant term $\kappa$ should not be statistically different from zero. A non-zero surplus would imply trend growth in debt. In contrast, fiscal policy is active if $\theta=0$ and $\kappa \neq 0$. We therefore assume that the reaction coefficients in (5) can change between two different states.

The debt response comes in addition to the systematic cyclical response of fiscal policy. ${ }^{3}$ If automatic stabilisers are let to work, then $\gamma$ is identical to the cyclical elasticity of the budget; the structural surplus is constant at its long-term level ceteris paribus. Typically, this elasticity is around 0.50 for OECD countries, but slightly smaller in Portugal (0.46, according to Girouard and André (2005)). If $\gamma$ is smaller than this elasticity, the surplus is procyclical.

We estimate the fiscal policy rule with a Markov Switching (MS) model in which the probability of each different regime - indicated by the state $m_{t}$ - of fiscal policy can vary endogenously over time. ${ }^{4}$

2 Note that a passive rule is not uniquely defined from the data generating process for surpluses and debt, and is observationally equivalent to an off-equilibrium behaviour that is consistent with active fiscal policies (Cochrane, 1998).

3 We take as an output measure the HP filtered output gap.

4 There are a few examples in the literature of regime switching tests of fiscal behaviour on US data. Davig (2004) examines the time varying probability of high and low debt regimes; Favero and Monacelli (2005) test a fiscal rule similar to (6). EU studies are fewer: Thams (2006) estimates fiscal rules for Germany and Spain; Claeys (2008) does so for Sweden. 


$$
s_{t}=\rho\left(m_{t}\right) s_{t-1}+\left(1-\rho\left(m_{t}\right)\right)\left[\kappa\left(m_{t}\right)+\gamma\left(m_{t}\right) x_{t}+\theta\left(m_{t}\right) b_{t}\right]+v_{t}\left(m_{t}\right) .
$$

In contrast to papers that test only the change in the debt response, or the symmetry of the cyclical response, we test for stochastic changes over time in all coefficients of (6). Additionally, we allow the variance of the shocks to switch between regimes. We estimate the MS model of the fiscal rule by maximum likelihood, using the ExpectationMaximization (EM) algorithm. There is no objective criterion to select the optimal number of regimes over which the coefficients can switch. Given the possibly two-sided responses in debt and output, there are potentially four different regimes. We start by imposing two regimes, and check the results for a higher number of states. ${ }^{5}$

\section{Empirical results}

\subsection{The fiscal policy rule}

Let us first look at the change in the parameters when the regime generating process is a two-state Markov chain. Table 1 reports the coefficient estimates of the fiscal rule (6) under regime 1 or 2 . We accordingly classify fiscal policy as 'active' or 'passive'. We also provide some additional statistics for each regime, such as the residual variance $\sigma^{2}$, the mean surplus and debt ratio, the number of observations and average duration of each regime. Finally, we calculate also the transition probabilities $p_{i j}$ between both states $i$ and $j$. Figure 3 plots the primary surplus ratio, and indicates with bars the probability of a given regime occurring in each quarter. The smooth and dashed lines show the predicted and smoothed probability of each regime in a given year. These probabilities are either based on the estimates up to that quarter, or on those of the entire sample.

Table 1 - Regimes in the fiscal rule (6), MS model, 2 regimes.

\begin{tabular}{cccccccccccccccccc}
\hline & label & $\rho$ & $\kappa$ & $\gamma$ & $\theta$ & $\sigma^{2}$ & $\begin{array}{c}\text { mean } \\
\text { debt }\end{array}$ & surplus & mean obs & duration & $p_{11}$ & $p_{22}$ \\
\hline regime 1 & active & $-0.58^{* *}$ & $-7.57^{* *}$ & 0.02 & $0.01 * *$ & 2.26 & 53.20 & -6.87 & 30.00 & 30.94 & 0.97 & 0.03 \\
\hline regime 2 & active & $0.22^{*}$ & $-2.78^{* *}$ & -0.44 & $0.31 *$ & 2.73 & 63.23 & -3.12 & 81.00 & 30.10 & 0.01 & 0.99 \\
\hline
\end{tabular}

Note: $p_{i j}$ is the transition probability from regime $i$ to $j ;{ }^{*}, * *-$ significance at 5 and $1 \%$.

5 All computations are done in MSVAR for Ox (Krolzig, 1998). 
Figure 3 - Regimes in the fiscal rule, MS model, 2 regimes.

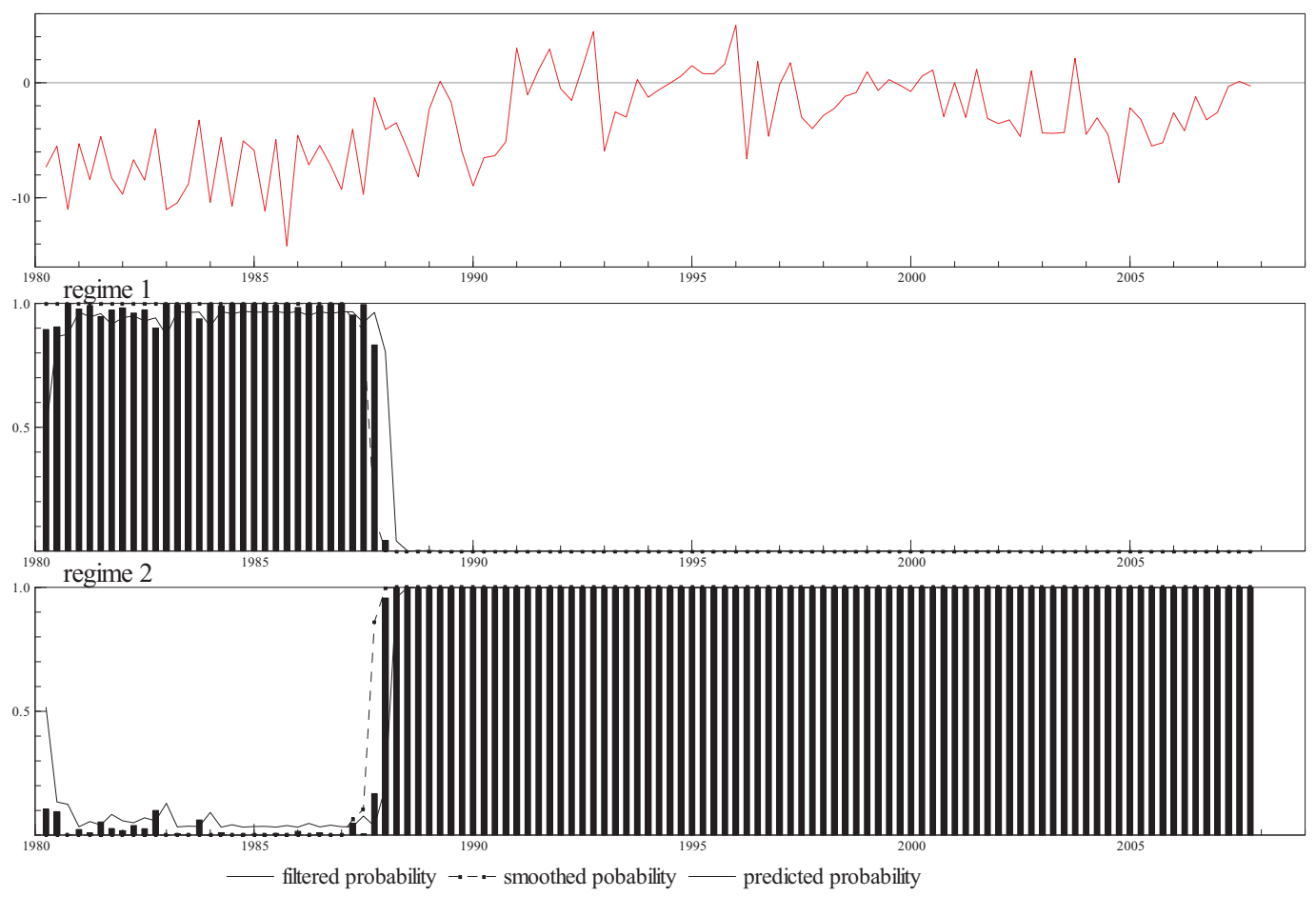

Figure 3 indicates a once and for all shift in 1988. The main reason for this change is the jump in the average surplus from $-6.9 \%$ to $-3.1 \%$ over the two periods. This turning point is much less outspoken for the other reaction coefficients: an active and acyclical policy becomes only slightly more passive and countercyclical after 1988 (Table 1). This change is not significant: fiscal policy continues to be unsustainable, so we can classify both periods as 'active' regimes. Without exception, other studies also confirm that government debt is on a non-sustainable path in Portugal (Afonso, 2005; Marinheiro, 2006; Guichard and Leibfritz, 2006).

A test of the fiscal rule under three different regimes refines our understanding of the change in fiscal policy (Table 2, Figure 4). Before 1988 (regime 1), deficits are high and the lack of a debt response still coincides with a lack of a cyclical response of the primary surplus. The period after 1988 can be split up into two distinct regimes. There are now relevant switches between active and passive policies. Under regime 2, the surplus is set to correct deviations in debt, while in regime 3, it is not. From Figure 4 , it is not immediately clear whether the fiscal rules of the Maastricht Treaty and the SGP have had a strong impact. Fiscal policy seems to have become more virtuous in preparation of EMU, and since the first EDP was started in 2002. But fiscal discipline has been hard to maintain, and fiscal consolidation was easily abandoned for a more relaxed stance. We can observe how quickly efforts to consolidate taper off once EMU 
membership was acquired in 1998. There is indeed little evidence that EU rules profoundly changed fiscal decisions in Portugal, or in other EU countries. Galí and Perotti (2003) or Balassone et al. (2008) test fiscal rules similar to ours and fail to find a structural break in 1992. Balassone and Francese (2004) do find a slightly stronger response to debt over time. We also see this gradual adjustment happening in Portugal, but it is not continued. Bayar and Smeets (2009) follow a very similar methodology as we do. They compute the transition probability of budget deficit over the cycle, and show that budget rules - like the 3\% limit in the SGP - seem to be more easily violated in Portugal than in other EU countries. Our findings for the most recent years confirm this.

Table 2 - Regimes in the fiscal rule, MS model, 3 regimes

\begin{tabular}{lc|ccccc|ccccccc}
\hline \hline & label & $\rho$ & $\kappa$ & $\gamma$ & $\theta$ & $\sigma^{2}$ & $\begin{array}{c}\text { mean } \\
\text { debt }\end{array}$ & $\begin{array}{c}\text { mean } \\
\text { surplus }\end{array}$ & \# obs & duration & $p_{11}$ & $p_{22}$ & $p_{33}$ \\
\hline regime 1 & active & $-0.58^{* *}$ & $-7.54^{* *}$ & 0.02 & $0.01^{* *}$ & 2.27 & 53 & 7.11 & 29.40 & 30.32 & 0.97 & 0.03 & 0.00 \\
regime 2 & passive & $-0.24^{*}$ & $-5.41^{* *}$ & $-1.15^{* *}$ & 0.58 & 2.05 & 65 & 3.46 & 41.80 & 8.89 & 0.00 & 0.89 & 0.11 \\
regime 3 & active & 0.05 & $-1.23^{*}$ & -0.09 & $0.36^{* *}$ & 1.92 & 62 & 2.69 & 39.80 & 10.48 & 0.00 & 0.10 & 0.90 \\
\hline \hline
\end{tabular}

Note: $p_{i j}$ is the transition probability from regime $i$ to $j ;{ }^{*},{ }^{* *}$-significance at 5 and $1 \%$.

Figure 4 - Regimes in the fiscal rule, MS model, 3 regimes.

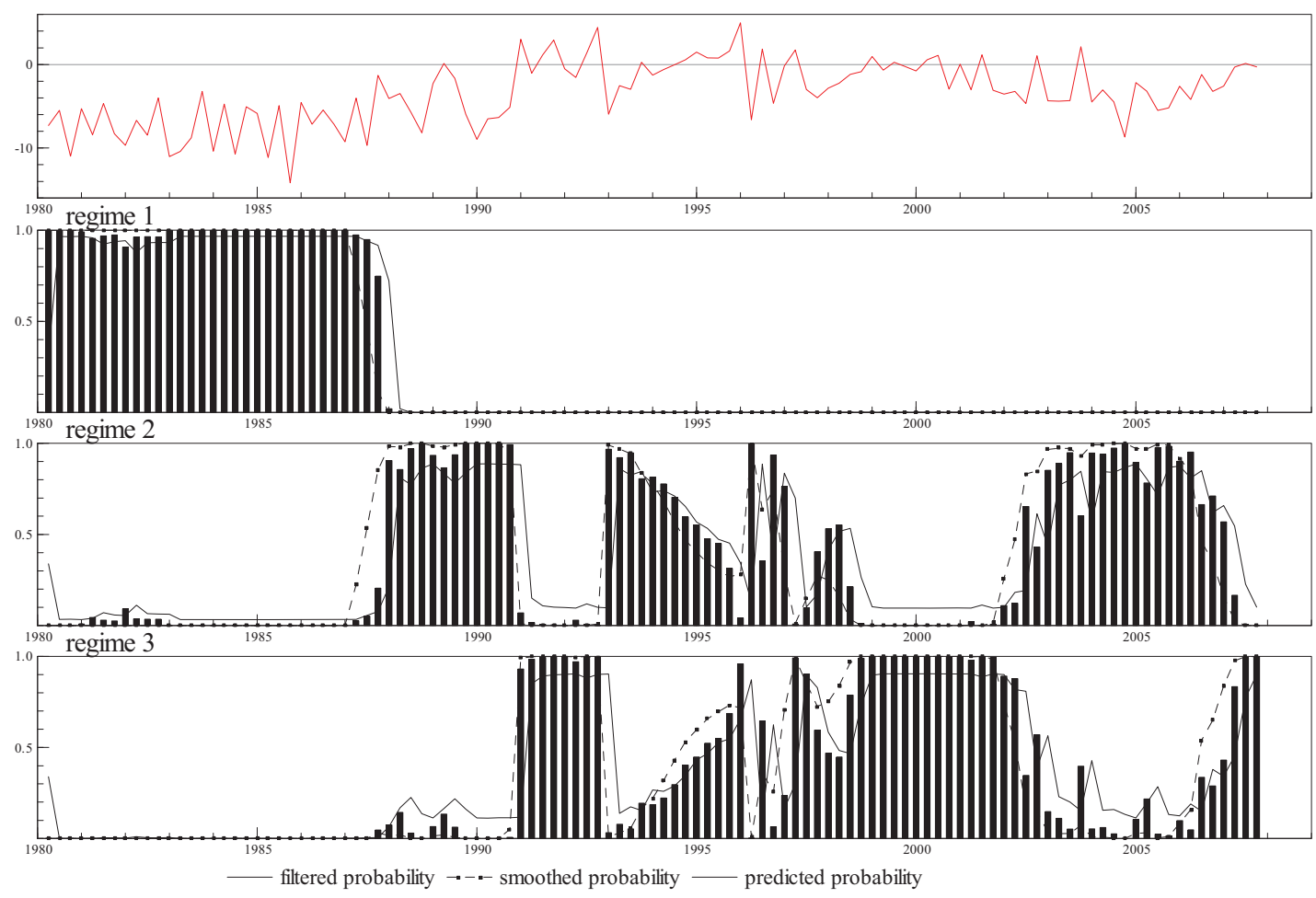


The other main finding is that the switch in the debt response coincides with a change in the cyclical stance. The budget is procyclical - with a cyclical elasticity of the budget is -1.15 - when it is consolidating, while in the other regime it is merely -0.09 . For example, in an economic crisis, the government cuts spending and raises taxes. As fiscal policy seems to have Keynesian effects in Portugal (Afonso and Sousa, 2009), this result implies that the government stabilises debt at the expense of a further destabilisation of the economy. Instead, under the other regime, fiscal policy does not magnify output fluctuations but does not take measures to stabilise debt either: There is substantial evidence that many EU governments frequently take discretionary measures that overturn the workings of automatic stabilisers (EC, 2001).

What explains the changes over time between policies that are active and acyclical, and periods in which policy becomes passive and procyclical? According to the 'tax smoothing' hypothesis, tax rates should be held constant over the business cycle and the budget deficit should move in a countercyclical fashion, for a given path of government spending. Keynesian models would also suggest adjusting taxes and spending in a countercyclical fashion to smooth the cycle. Procyclical policies exacerbate economic instability as the distortionary effect of taxation becomes larger, and consequently stifle growth. This may actually explain a large part of macroeconomic instability in Portugal. ${ }^{6}$ Table 3 shows that the volatility of GDP in Portugal, measured by the standard deviation of the real GDP growth rate, is on the high end for EU countries ${ }^{7}$

Table 3 - Output volatility in the EU (1970-2007).

\begin{tabular}{ll|ll}
\hline \hline Germany & 1.16 & Italy & 1.85 \\
France & 1.38 & UK & 1.89 \\
Netherlands & 1.52 & Spain & 1.97 \\
Austria & 1.61 & Finland & 2.70 \\
Belgium & 1.71 & Ireland & 2.77 \\
Sweden & 1.75 & Portugal & 3.08 \\
Denmark & 1.84 & Greece & 3.22 \\
\hline \hline \multicolumn{2}{c}{ Note: standard deviation of real GDP growth. }
\end{tabular}

\footnotetext{
${ }^{6}$ Afonso and Claeys (2008) show that fiscal policy indeed contributes much more to the variance in output developments in Portugal than in other EU countries.

7 Note that if we do not allow for a change in volatility, the estimated coefficients of the AR model are not stable and the switches are randomly distributed over the sample period.
} 


\subsection{Procyclical policy changes and electoral cycles}

There are several theories giving a rationale as to why policymakers favour using suboptimal procyclical policies. The leading theory is that governments are cut off from credit lines when an economic crisis hits. Without additional bond or tax financing, governments have no choice but to cut spending as tax revenues falter. This starving of public expenditure is a recurrent phenomenon in developing economies (Gavin and Perotti, 1997). For an OECD country like Portugal, it is unlikely that credit markets restrict financing. Capital markets have continued to buy Portuguese government bonds in the past. The declining long-term government bond interest rates, with limited spreads vis-à-vis the German benchmark, are further proof of the continued financing of budget deficits. Despite recent downward revisions, sovereign debt ratings have continued to be high (Table 4).

Table 4 - Long-term sovereign debt credit ratings.

\begin{tabular}{l|ccc|ccc|ccc}
\hline \hline & \multicolumn{3}{|c|}{ Fitch } & \multicolumn{3}{c|}{ S\&P } & \multicolumn{3}{c}{ Moody's } \\
\cline { 2 - 10 } & $\begin{array}{c}\text { foreign } \\
\text { currency }\end{array}$ & $\begin{array}{c}\text { local } \\
\text { currency }\end{array}$ & outlook & $\begin{array}{c}\text { foreign } \\
\text { currency }\end{array}$ & $\begin{array}{c}\text { local } \\
\text { currency }\end{array}$ & outlook & $\begin{array}{c}\text { foreign } \\
\text { currency }\end{array}$ & $\begin{array}{c}\text { local } \\
\text { currency }\end{array}$ & outlook \\
\hline 1990 & & & A & & positive & A1 & \\
1995 & AA- & AAA & & AA- & AAA & stable & A1 & & Aable \\
2000 & AA & AA & stable & AA & AA & stable & Aa2 & Aa2 & stable \\
2005 & AA & AA & negative & AA- & AA- & stable & Aa2 & Aa2 & stable \\
2007 & AA & AA & negative & AA- & AA- & stable & Aa2 & Aa2 & stable \\
2009 & AA & AA & negative & A+ & A+ & negative & Aa2 & Aa2 & stable \\
\hline \hline
\end{tabular}

Financial markets take the decision to continue financing fiscal imbalances by considering some fiscal indicator of sustainability. Large swings in this measure might indicate recurrent financing problems. We estimate an $\mathrm{AR}(4)$ model for the debt stabilising surplus, and allow the mean and variance to shift between two latent states. ${ }^{8}$ Results of this MS model do not show large swings, but a gradual shift - starting in 1995, and completed by 1998 - from a period of low and volatile, to a regime of higher and less rapidly changing surpluses. ${ }^{9}$ Past fiscal procyclicality cannot be due to some market disciplining corrections during downturns.

Other theories see procyclical policies as the outcome of a political distortion in the budget process. The basic tenet of these models is that fiscal surpluses - in economic booms - will generate political pressures for additional public spending or tax

\footnotetext{
${ }^{8}$ Results not reported, but available on request.

${ }^{9}$ As in Davig (2004), we also estimate an AR(4) model for the debt ratio. As debt is a non-stationary series, the regime estimates are not stable. This confirms our previous finding that fiscal policy is active.
} 
cuts. Talvi and Vegh (2005) present a model in which a fiscal surplus raises lobbying efforts for higher public spending. A benevolent social planner can limit this spending bias by cutting taxes during the boom. This undermines the financing base for additional spending. Moreover, fiscal policy is not only expansionary in good times, but also contractionary in bad times. The government raises taxes in crises to avoid accumulating debt. The optimal policy is procyclical over the entire cycle. The larger are economic fluctuations - and hence changes in the tax base - the more procyclical is fiscal policy. ${ }^{10}$

Two different - but not mutually exclusive - political theories explain the distortion at the root of the increased lobbying efforts in booms. On the one hand, Lane and Tornell (1996) and Tornell and Lane (1999) argue that multiple power blocs (ministries, lobby groups, etc.) compete for a bigger share in spending. On the other hand, Alesina et al. (2008) assume that voters have imperfect information on the budget process. In order to avoid that corrupt governments distribute tax revenues to particular interest groups, voters anticipate this, and appropriate part of the additional tax revenues in economic booms by voting for increases in their preferred public good, or a tax cut. This forces the government to a procyclical bias in taxation. As fiscal revenues increase in an economic boom, more resources are available, and this increases the level of competition. Spending may even grow more than proportionally relative to the increase in income. The same argument for the excess rise in spending can also lead to a disproportionate fall in taxation: if interest groups call for tax reductions for their constituency, the political distortion could also induce too low taxation in booms.

Empirical studies find evidence for political cycles in the surplus on a panel of EU countries (Golinelli and Momigliano, 2006; Hallerberg and Strauch, 2003). For Portugal, we overlay in Figure 5 the debt stabilizing surplus with the three regime MSestimates of the fiscal surplus rule obtained before. The vertical lines indicate the quarter in which parliamentary elections took place. The Portuguese electoral system favours one party majority, and we indicate the governing party ( $P S$ 'Socialist Party' or PSD 'Social Democratic Party') for every term. These election periods indeed coincide with shifts from a procyclical passive to an acyclical active policy. The reasons for the change are less obvious. It occurs when power is handed over, but also when the governing party remains in charge. In addition, at the time of the switch, the surplus may either fall or rise.

10 This model takes large fluctuations in tax bases as exogenous. 
Figure 5 - Elections and regimes in the fiscal rule.

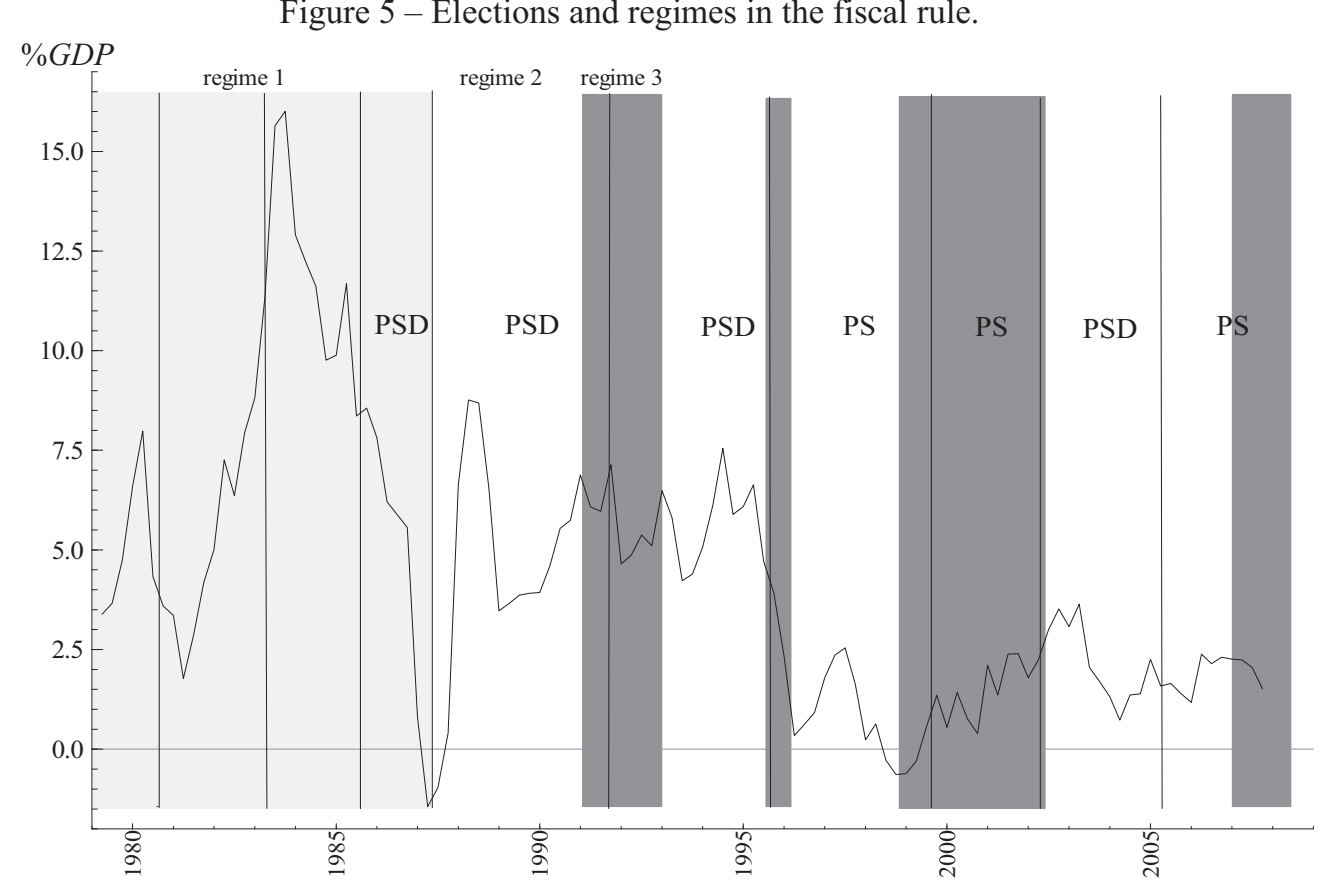

Note: vertical lines denote the parliamentary elections (source: Census).

\subsection{Procyclical fiscal policies}

Changes in the policy stance follow from a combination of time varying spending and tax policies. We now expand the evidence on the fiscal rule, and test changes in the response of government spending over time. The government decides on primary spending in response to the cycle and the debt stabilising surplus. We assume again a two state Markov chain for the evolution of the latent process. If spending is the left hand side variable, the fiscal regime is active (passive) if $\theta=0(\theta<0)$ in equation (6). We allow for trend growth in spending or taxes. Hence, we drop the restriction of the constant term $\kappa$ being equal to zero. The cyclical variability in spending should be relatively minor. Computations of budget elasticities by the OECD assume that only unemployment benefits vary over the cycle. Other budget components are assumed to be cyclically insensitive. Girouard and André (2005) find an overall spending elasticity of -0.05. A countercyclical spending policy would imply a significantly smaller elasticity.

For tax revenues, we can similarly specify a fiscal rule, and test the time varying responses. If tax revenue is the left hand side variable, the fiscal regime is active (passive) if $\theta=0(\theta>0)$ in equation (6). The output elasticity of government revenues is based on the properties of each tax item (viz. social security contributions, corporate, personal and indirect taxes) and the elasticity of the tax bases to output. OECD figures 
put this number at 0.47 for overall revenues (Girouard and André, 2005). Significantly smaller numbers indicate a procyclical tax policy.

The results reported in Table 5 reveal that spending is the main thrust behind the debt bias. We find that both regimes are active: fiscal consolidation on the spending side has never taken place. This continued growth of primary spending casts doubt on longterm fiscal sustainability. The pace of spending growth has nonetheless slowed down since about the introduction of the Maastricht rules. But this break is not substantial, and there are several episodes in which spending shoots up quickly again (1997 and 2005). Figure 6 plots the spending ratio, together with the election dates and the two regimes. Large rises in spending do not usually occur just before or after elections. They do coincide with shifts to a less sustainable policy in the most recent episodes (1997 and 2005). This political cycle has become weaker since the late nineties. Spending has stabilised at an unsustainable level, albeit with a continued weak response to the cycle.

Table 5 - Regimes in the primary spending rule, MS model, 2 regimes.

\begin{tabular}{|ll|cccc|ccccc|cc|}
\hline \hline & label & $\kappa$ & $\gamma$ & $\theta$ & $\sigma^{2}$ & $\begin{array}{c}\text { mean } \\
\text { debt }\end{array}$ & $\begin{array}{c}\text { mean } \\
\text { spending }\end{array}$ & $\begin{array}{c}\text { mean } \\
\text { surplus }\end{array}$ & \# obs & duration & $\mathrm{p}_{11}$ & $\mathrm{p}_{22}$ \\
\hline regime 1 & active & $41.47^{* *}$ & 0.02 & $0.07 * *$ & 1.79 & 59 & 36 & 2.82 & 66.40 & 23.46 & 0.96 & 0.04 \\
regime 2 & active & $47.55^{* *}$ & -0.34 & $0.01 * *$ & 3.07 & 63 & 37 & 6.42 & 44.60 & 15.51 & 0.06 & 0.94 \\
\hline \hline
\end{tabular}

Note: $p_{i j}$ transition probability from regime $\mathrm{i}$ to $\mathrm{j} ;{ }^{*},{ }^{* *}-$ significance at 5 and $1 \%$.

Figure 6 - Regimes in the primary spending rule, MS model, 2 regimes.

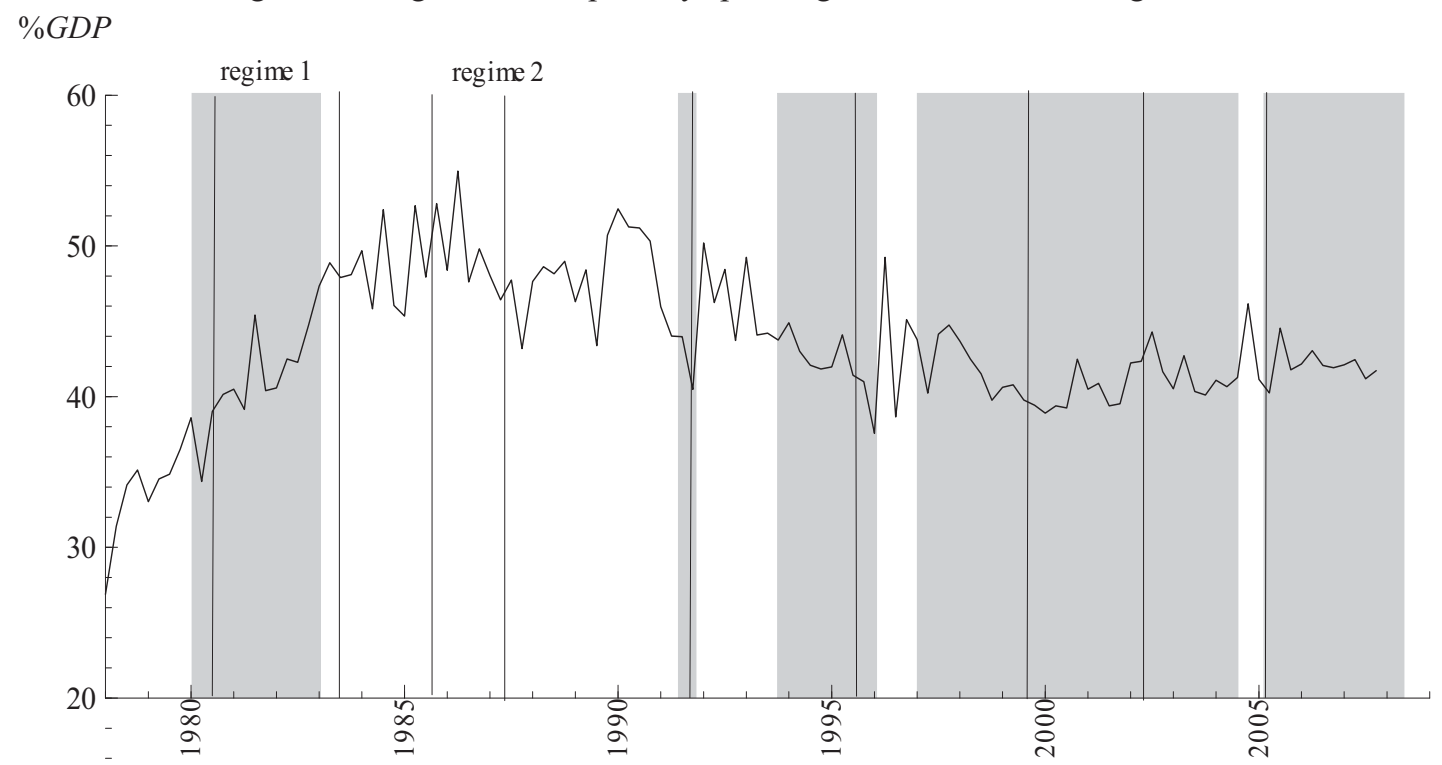

Note: vertical lines denote the parliamentary elections (source: Portuguese Parliament). 
Our findings regarding the surplus rule in Table 1 say that fiscal policy becomes slightly more sustainable over time. Given the drift in public spending, public finances must thus be consolidated with tax increases. However, there is not much evidence of switches in the parameters of the tax rule (Table 6). Although we observe a gradual rise in tax revenues over time, this shift has not been strong enough to make tax policy passive. According to Bronchi and Santos-Gomes (2001), the 1989 tax reform that broadened the tax base and introduced statutory tax rates did not contribute much to consolidation and this is also featured in our analysis (Figure 7). Only since about 1994, and under the influence of the Maastricht rules, did tax policies become more responsive to government debt. Nonetheless, this type of tax policy has not been maintained permanently. In fact, taxes responded much less to debt in 1997 and over the period 2003-2005.

Table 6 - Regimes in the tax rule, MS model, 2 regimes.

\begin{tabular}{|c|c|c|c|c|c|c|c|c|c|c|c|c|}
\hline & label & $\kappa$ & $\gamma$ & $\theta$ & $\sigma^{2}$ & $\begin{array}{c}\text { mean } \\
\text { debt }\end{array}$ & $\begin{array}{c}\text { mean } \\
\text { revenue }\end{array}$ & $\begin{array}{c}\text { mean } \\
\text { surplus }\end{array}$ & \# obs & duration & $\mathrm{p}_{11}$ & $\mathrm{p}_{22}$ \\
\hline regime 2 & active & $34.84 * *$ & $-0.28 *$ & 0.03 & 1.18 & 63 & 35 & 2.89 & 64.70 & 26.36 & 0.04 & 0.96 \\
\hline
\end{tabular}

Note: $p_{i j}$ is the transition probability from regime $\mathrm{i}$ to $\mathrm{j} ;{ }^{*},{ }^{* *}$-significance at 5 and $1 \%$.

Figure 7 - Regimes in the tax rule, MS model, 2 regimes.

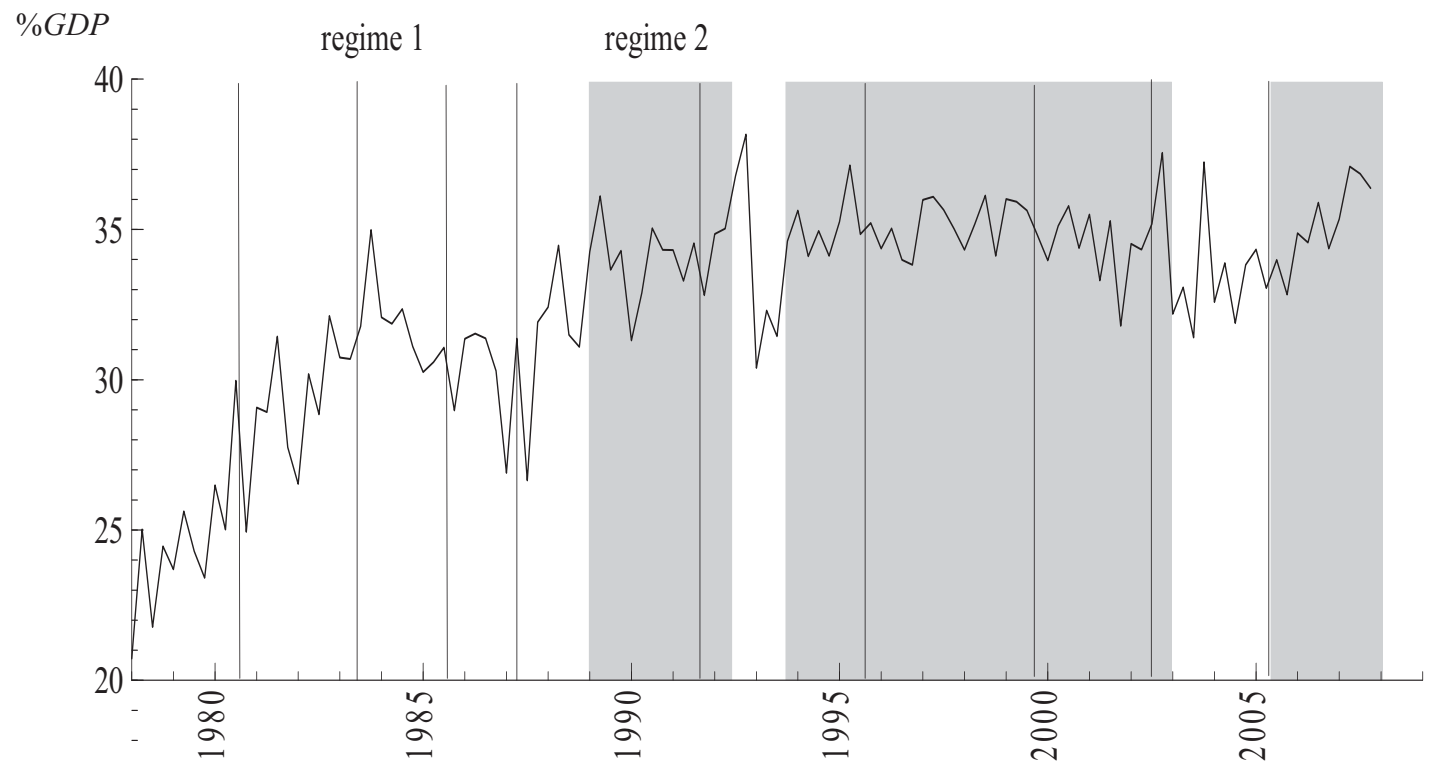

Note: vertical lines denote the parliamentary elections (source: Portuguese Parliament). 
Surprisingly, tax policy has been procyclical under both regimes. This is in contrast to other studies that usually argue that a procyclical surplus is due to government spending (Lane, 2003). Even though taxation is procyclical over the entire sample, the government budget happens to be procyclical in three specific periods only: the late eighties, around 1995, and in the period 2002-2005. In those years, the cyclical responses of the budget via automatic stabilisers were offset by discretionary tax measures. An economic boom at the end of the eighties did not seem to be used for structural consolidation. The 1986 episode has had more features of an adjustment on the spending side. Government debt fell as economic growth rose, but little else was done to bring down the deficit. Despite the introduction of VAT, tax revenues did not raise much. The two other periods are marked by economic slumps. The consolidation episode of 1992 was mainly focused on tax increases. The 1993 economic downturn in Europe reduced tax income, and primary spending rose significantly too that year. The government used privatisation revenues amounting to 2 per cent of GDP for debt redemption. The economic boom of the mid nineties was foregone as a moment to implement structural adjustment. The economic decline starting in 2001 put again under strain the budget. The government resorted once more to temporary measures to control the deficit. In 2002, the government granted a tax amnesty; in 2003, tax credits were securitized. This consolidation strategy also included an increase in the standard VAT rate from 17 to 19 per cent, which was further raised to 21 per cent in July 2005. These temporary measures added up to 6.2 per cent of GDP over the period 2002-2005.

The increase in tax revenues during economic crisis avoided a further worsening of the budget deficit, but did not address the structural factors behind the underlying fiscal imbalances. Due to a lack of structural measures in good economic times, surging deficits urged consolidation in economic crisis. Consolidation has been temporary and aimed at reducing the budget deficit in the short-run (Guichard and Leibfritz, 2006). Such focus on tax based consolidations with yearly switches in tax policy has undermined the success of fiscal consolidations (Pina, 2004).

\subsection{Cyclical asymmetry in the budget, and debt accumulation}

The patterns that we uncovered in spending and tax policy closely follow the predictions of the Talvi and Vegh (2005) model: taxes are insufficiently raised to finance higher spending, and taxation is increased only if mounting imbalances urge a fiscal adjustment. However, models of procyclical policy cannot explain the debt bias in 
fiscal policy. Procyclical policies deliberately create deficits in economic booms, and follow a more restrictive stance in economic crisis. As a consequence, they stabilise the deficit. A debt bias can only occur if deficits in a crisis are not offset by sufficiently large surpluses in economic booms.

From the estimation of the surplus rule, we have evidence that the change in the debt response of the budget is associated with the cyclical response (Table 2, Figure 4). The failure to take tax measures in good economic times becomes even clearer if we look at some additional evidence on the asymmetric reaction of the budget to positive and negative cyclical conditions. We estimate the fiscal rules on the full sample, but test if the response to positive or negative output gaps differs. The results are summarized in Table 7, and show that fiscal policy indeed reacts asymmetrically to cyclical conditions. An upturn is accompanied by a strong deterioration of the overall budget (elasticity of 0.94) while a downturn does not worsen the balance significantly. Taxes are cut in economic booms, with overall revenues falling despite the increase in the tax bases. Moreover, taxes are not raised back in a crisis to a similar extent. ${ }^{11}$ Government spending does not respond to the changes in the cycle, neither in a boom nor during a recession.

Table 7 - Fiscal rule, full sample, positive versus negative output gap.

\begin{tabular}{l|cccc}
\hline \hline & $\kappa$ & $\gamma^{+}$ & $\gamma^{-}$ & $\theta$ \\
\hline surplus rule & $-1.34 * * *$ & $-0.94 * *$ & 0.78 & -0.08 \\
spending rule & $41.35^{* * *}$ & 0.26 & -0.38 & $0.50 * *$ \\
tax rule & $34.98^{* * *}$ & $-0.80^{* *}$ & 0.29 & -0.16 \\
\hline \hline Note: $\gamma^{+}, \gamma^{-}$responses to positive and negative output gaps.
\end{tabular}

Budget decisions in other EU countries are taken in a similar procyclical way. There is ample evidence of a fiscal relaxation in good times that is not offset by a tightening in downturn. ${ }^{12}$ Governments loosen the fiscal stance by the size of the additional tax revenues in good times, but let the balance deteriorate as soon as economic conditions start to worsen (Manasse, 2006; Beetsma and Giuliodori, 2008). ${ }^{13}$ But the results for Portugal are even stronger than what is typically found for other EU

11 This is further evidence that procyclical policies are not due to falling credit ratings.

12 See the studies by Buti and Sapir (1998), Buti et al. (1998), EC (2001), Von Hagen et al. (2002), and Balassone et al. (2008).

13 Golinelli and Momigliano (2006) argue that the findings of asymmetric procylical policies depend on the way fiscal policy is modelled. Using real time data to test fiscal rules, they find that governments genuinely react in a countercyclical and symmetric way to the cycle. 
countries. First, in Portugal, the budget surplus actually falls in economic booms, while it rises - albeit insignificantly - in economic crises. Discretionary measures have not just undermined automatic stabilisers, but have overturned them. Second, for most EU countries, this asymmetry is due to buoyant spending in economic booms (Balassone et al., 2008). For instance, Hercowitz and Strawczynski (2004) show that in other OECD countries spending goes up during booms, but it does not come down in recessions. In contrast, this growth dividend has been used for cutting taxes while keeping the surplus in check in Portugal. Tax reductions can be financed while the government is not seen as irresponsible with public finances.

The results in Table 7 also confirm that fiscal policy is not sustainable. The insignificant response of the surplus to the rise in debt is a combination of continued spending and less responsive tax revenues. As in other EU countries, debt accumulates if fiscal policy refrains from taking similarly sized contractionary measures in the downside part of the cycle. We indeed find no evidence of spending cuts in crises while tax increases are rather moderate in bad times.

The asymmetry in the cyclical response can be explained in three different ways. First, interest groups can be so voracious that tough lobbying in booms can create excessive borrowing. Therefore, tax cuts or spending hikes may be more than proportional to GDP growth. Second, the intensity of lobbying is likely to decrease in recessions. Lobbying groups or uninformed tax payers compete less on (or try to avoid) spending cutbacks or tax rises in a recession. Finally, political opportunism may interact with the mounting pressures in economic booms. Governments may lower taxes in a boom and seemingly maintain the deficit in check. The impact on the deficit (and debt) becomes clear only in the next recession. Politicians can do so strategically to constrain successor governments (Alesina and Tabellini, 1990) or to raise the probability of reelection now (Aghion and Bolton, 1990).

\subsection{Power dispersion and budget fragmentation: an interpretation}

What could explain the reluctance to raise taxes in economic booms? One prediction of the models of procyclical policy is that volatile economic cycles exacerbate the policy distortions. In countries with volatile output, different pressure groups repeatedly compete over a fluctuating level of resources. Tax cuts or spending hikes may then be more than proportional to GDP growth. As we showed in Table 3, the volatility of output in Portugal is among the highest in the OECD. However, given 
that procyclical policies worsen the economic distortions of taxation, it is likely that a large part of the fluctuations in GDP is due to fiscal policy itself.

The voracity model of procyclical policy argues that the common pool problem - on spending or taxation - is more severe when power is diffused among a larger number of agents. Different interest groups lobby more intensively for a higher share. Henisz (2000) constructs an index of power dispersion that counts the number of veto points in the political system and the distribution of preferences across and within the different branches of the government. Table 8 compares this index for EU countries, and we see that although competition among political groups exists in Portugal, it is not stronger than in other EU countries.

Table 8 - Power dispersion in EU countries.

\begin{tabular}{ll|ll}
\hline \hline Germany & 0.85 & Italy & 0.75 \\
France & 0.74 & UK & 0.74 \\
Netherlands & 0.73 & Spain & 0.75 \\
Austria & 0.74 & Finland & 0.77 \\
Belgium & 0.89 & Ireland & 0.75 \\
Sweden & 0.77 & Portugal & 0.75 \\
Denmark & 0.77 & Greece & 0.38 \\
\hline \hline Source: Henisz (2000).
\end{tabular}

Procyclicality also occurs when the budget process is not very transparent. Voters might pressure governments to reduce taxation if they have little information on the way public spending is distributed (Alesina et al., 2008). Several OECD reports point to shortcomings in the budget management process in Portugal and in the planning and control of public spending (Bronchi, 2003). There have also been data limitations in the past that prevented accurate monitoring of the outcomes of public finances. ${ }^{14}$ In recent years, several steps have been taken to control these loopholes in budget making (Curristine et al., 2008).

There is some evidence that in Portugal, the budget process is also particularly complex and fragmented. Table 9 reports a number of indicators of budgeting procedures, collected by the OECD (1995), Hallerberg and Von Hagen (1997) and

\footnotetext{
${ }^{14}$ For example, a specific commission - under the aegis of the central bank - was created in 2002 to determine the size of the 2001 budget deficit. The revised number showed a much higher deficit than previously reported, and triggered the first EDP. A similar revision in 2005 doubled the initial deficit, and set off the second EDP.
} 
Perotti and Kontopolous (2002). These indicators look at the existence of a spending target, who decides on this target, and the way budget negotiations among government members take place. In Portugal, decision making on the budget of the central government seems quite lax and complicated compared to other EU countries. There is no overall spending target that serves as a cap on the budgeting decisions. No legislated quantitative limits or procedural rule on the budget exists in Portugal, except for the limits set by the SGP. ${ }^{15}$ Moreover, negotiations on the budget take place between all cabinet members, which strengthens the position of different ministries vis-à-vis the minister of finance. Of all EU countries, Portugal ranks worst - together with Greece if we look at the sum of all indicators. A similar indication is given by the synthetic index of strength of fiscal rules in EU countries that is calculated by the EC (2006). This index places Portugal at the bottom end of the indicator.

Table 9 - Fragmentation of the budget process.

\begin{tabular}{|c|c|c|c|c|c|}
\hline & Spending target & Spending target & Spending & Negotiation & $\overline{\text { Sum }}$ \\
\hline & $\begin{array}{l}0 \text { if determined by } \\
\text { Finance Minister; } 1 \\
\text { if cabinet decides; } \\
2 \text { if no target }\end{array}$ & $\begin{array}{l}1 \text { if no spending } \\
\text { target } \\
1995)\end{array}$ & $\begin{array}{l}1 \text { if no spending } \\
\text { target (Hallerberg } \\
\text { and Von Hagen, } \\
\text { 1997) }\end{array}$ & $\begin{array}{l}1 \text { if multilateral } \\
\text { negotiation } \\
\text { between } \\
\text { government } \\
\text { members }\end{array}$ & \\
\hline Germany & 0 & 0 & $1 / 0$ & 0 & 1 \\
\hline France & 2 & 1 & 1 & 0 & 4 \\
\hline Netherlands & 1 & 0 & 0 & 0 & 1 \\
\hline Austria & 0 & 0 & 0 & 0 & 0 \\
\hline Belgium & 2 & 1 & 1 & 0 & 4 \\
\hline Sweden & 2 & 1 & 1 & 0 & 4 \\
\hline Denmark & 0 & 0 & 0 & 0 & 0 \\
\hline Italy & 2 & 1 & 1 & 0 & 4 \\
\hline UK & 1 & 0 & 1 & 0 & 2 \\
\hline Spain & 2 & 1 & 1 & 0 & 4 \\
\hline Finland & 2 & 1 & 0 & 0 & 4 \\
\hline Ireland & 1 & 0 & 0 & 0 & 1 \\
\hline Portugal & 2 & 1 & 1 & 1 & 5 \\
\hline Greece & 2 & 1 & 1 & 1 & 5 \\
\hline
\end{tabular}

Source: Perotti and Kontopoulos (2002).

\section{Conclusion}

Using a new dataset of quarterly fiscal series drawing on high frequency cash data, we apply Markov Switching techniques to track the developments in fiscal policy in Portugal over the period 1978-2007. Our main finding is that the behaviour of fiscal policy has hardly become more stable or sustainable. Improvements in budgetary

\footnotetext{
15 Manasse (2006) finds that fiscal rules tend to reduce procyclicality if the overall quality of budget institutions is low.
} 
positions are essentially linked to low real interest rates and high economic growth, which eased the application of the Maastricht rules in the nineties, but hardly to structural measures.

Repeated reversals of tax policy have made fiscal policy procyclical. Economic booms are used to relax tax pressures, often for electoral purposes. These measures are only partially undone in the next economic crisis to contain mounting deficits. These sudden changes in the policy stance have also been harmful to economic stability. In addition, a lax control on spending has contributed to the rise in debt. The constraints imposed by the Maastricht criteria and by the SGP have contained deficits but at the same time accentuated these budgeting problems.

We argue that uncontrolled and non-transparent decisions on fiscal adjustment are the root of the problem with fiscal policy. One-off measures have often been preferred over structural measures to contain the deficit during economic crises. The chronic weak control of government spending, combined with an imprecise monitoring of the implementation of the budget have worsened this situation. Voters that can only imperfectly control the government budget likely prefer tax cuts in economic booms to keep at bay additional spending (Alesina et al., 2008).

Portugal has faced difficulties since 2002 in implementing fiscal consolidations. At the same time, such difficulties create an opportunity to introduce structural reform measures. An overhaul reform of budget procedures - such as the introduction of fiscal rules - and a stricter surveillance of the budget will not only save public finance in the long-term, but also benefit economic stability in the short-term. Some headway in this direction has been made already (Curristine et al., 2008).

\section{References}

Afonso, A. (2005). "Fiscal Sustainability: the Unpleasant European Case," FinanzArchiv, 61(1), 19-44.

Afonso, A. and Claeys, P. (2008). "The dynamic behaviour of budget components and output," Economic Modelling, 25 (1), 93-117.

Afonso, A. and Sousa, R. M. (2009). "The macroeconomic effects of fiscal policy," ECB Working Paper No. 991.

Aghion, P. and Bolton, P. (1990). "Government Domestic Debt and the Risk of Default: A Political-Economic Model of the Strategic Role of Debt.” In: Dornbusch, R. and Draghi, M. (eds.) Public debt management: Theory and history, London: CEPR. 
Alesina, A. and Tabellini, G. (1990). "A positive theory of fiscal deficits and government debt," Review of Economic Studies, 57(3), 403-414.

Alesina, A., Campante, F., and Tabellini, G. (2008). "Why is Fiscal Policy Often Procyclical?", Journal of the European Economic Association, 6(5), 1006-1036.

Balassone, F. and Francese, M. (2004). "Cyclical Asymmetry in Fiscal Policy, Debt Accumulation and the Treaty of Maastricht," Bank of Italy Working paper No. 531.

Balassone, F., Francese, M., and Zotteri, S. (2008). "Cyclical asymmetry in fiscal variables," Bank of Italy Working Paper No. 671.

Bayar, A. and Smeets, B. (2009). "Government Deficits in the European Union: An Analysis of Entry and Exit Dynamics," Cesifo Working Paper No. 2703.

Bronchi, C. (2003). "The effectiveness of public expenditure in Portugal," OECD Working Paper No. 349.

Bronchi, C. and Gomes-Santos, J. (2001). "Reforming the tax system in Portugal," OECD Working Paper No. 302.

Buti, M., Daniele, F., and Ongena, H. (1998). "Fiscal Discipline and Flexibility in EMU: The Implementation of the SGP," Oxford Review of Economic Policy, 14(3), 81-97.

Buti, M. and Sapir, A. (1998). "Economic policy in EMU: A study by the European Commission Services," Oxford: Oxford University Press.

Claeys, P. (2008). "Rules, and their effects on fiscal policy," Swedish Economic Policy Review, 15(1), 7-48.

Cochrane, J. H. (1998) “A frictionless view of U.S. inflation”. In Bernanke, B. and Rotemberg, J. (eds.), NBER Macroeconomics Annual, 13(1), Cambridge: MIT Press.

Curristine, T., Park, C., and Emery, R. (2008). "Budgeting in Portugal," OECD Journal on Budgeting, 3, 1-60.

Davig, T. (2004). "Regime-switching debt and taxation," Journal of Monetary Economics, 51, 837-859.

EC (2001). "Public Finances in EMU,” European Commission.

EC (2006). "Public finances in EMU," European Commission.

Favero, C. and Monacelli, T. (2005). "Fiscal policy rules and regime (in) stability: evidence from the US," IGIER Working Paper No. 282. 
Galí, J., and Perotti, R. (2003). "Fiscal policy and monetary integration in Europe," Economic Policy, 37, 535-572.

Gavin, M. and Perotti, R. (1997). "Fiscal Policy in Latin America," In Bernanke, B. and Rotemberg, J. (eds.). NBER Macroeconomics Annual 1997. Cambridge: MIT Press.

Girouard, N. and André, C. (2005). "Measuring cyclically adjusted budget balances for OECD countries," OECD Economics Department Working Paper No. 434.

Giuliodori, M. and Beetsma, R. (2008). "On the relationship between fiscal plans in the European Union: An empirical analysis based on real-time data," Journal of Comparative Economics, 36(2), 221-242.

Golinelli, R. and Momigliano, S. (2006). "Real-time determinants of fiscal policies in the euro area," Journal of Policy Modeling, 28 (9), 943-964.

Guichard, S. and Leibfritz, W. (2006). “The Fiscal Challenge in Portugal," OECD Working Paper No. 489.

Hallerberg, M., Von Hagen, J. (1997). "Sequencing and the size of the budget: A reconsideration," CEPR working paper No. 1589.

Hallerberg, M. and Strauch, R. (2002). "On the cyclicality of public finances in Europe," Empirica, 29(3), 183-207.

Henisz, W. (2000). "The institutional environment for economic growth," Economics and Politics, 12 (1), 1-31.

Hercowitz, Z. and Strawczynski, M. (2004). "Cyclical Ratcheting in Government Spending: Evidence from the OECD," Review of Economics and Statistics, 86 (1), 353-361.

Krolzig, H (1998). “Markov Switching Vector Auto-regressions,” Berlin: Springer.

Lane, P. (2003). "The cyclical behaviour of fiscal policy: evidence from the OECD," Journal of Public Economics, 87(12), 2661-2675.

Lane, P. and Tornell, A. (1996). "Power, growth, and the voracity effect," Journal of Economic Growth, 1, 213-241.

Manasse, P. (2006). "Procyclical Fiscal Policy: Shocks, Rules, and Institutions: A View From MARS," IMF Working Paper No. 27.

Marinheiro, C. (2006). "Sustainability of Portuguese Fiscal Policy in Historical Perspective," Empirica, 33(2-3), 155-179.

OECD (1995). “Budgeting for results," OECD, Paris. 
Perotti, R. and Kontopoulos, Y. (2002). "Fragmented fiscal policy," Journal of Public Economics, 86(2), 191-222.

Pina, A. (2004). "Fiscal Policy in Portugal: Discipline, Cyclicality and the Scope for Expenditure Rules," proceedings of the 2nd Conference on Portuguese Economic Development in the European Context, held by the Bank of Portugal in Lisbon, $11-12,15-65$.

Sims, C. (1994), "A simple model for study of the determination of the price level and the interaction of monetary and fiscal policy," Economic Theory, 4(3), 381-399.

Talvi, E. and Vegh, C. (2000). "Tax base variability and procyclical fiscal policy," NBER Working Paper No. 7499.

Thams, A. (2006). "Fiscal policy effects in the European Union," SFB Discussion Paper No. 649.

Tornell, A. and Lane, P. (1999). "The voracity effect," The American Economic Review, 89(1), 22-46.

von Hagen, J., Hughes-Hallett, A. and. Strauch, R.(2002). "Quality and Success of Budgetary Consolidation," in Buti, M., Martinez-Mongay, C. and von Hagen, J. (eds.) The Behaviour of Fiscal Authorities - Stabilization, Growth and Institutions, London: Palgrave.

\section{Appendix - Data description and sources}

GDP

data are quarterly, seasonally adjusted, period: 1978:1-2007:4. Source: Bank of Portugal.

Deflator

all variables were deflated by the GDP deflator $(2000=100)$. Data are quarterly, seasonally adjusted, period: 1978:1-2007:4. Source: Bank of Portugal.

\section{Government Spending}

defined as Central Government primary spending (on a cash basis), i.e. the difference between authorized expenditure and debt interest payments. We seasonally adjust quarterly data using Census X12 ARIMA, period 1978:1-2007:4. Source: Bank of Portugal.

Government Revenue

defined as Central Government total revenue (on a cash basis). We seasonally adjust quarterly data using Census X12 ARIMA. period 1978:1-2007:4. Source: Bank of Portugal.

Debt 
is defined as the stock of Direct State Debt. The original series are available as follows:

1. for the period 1997:12-1994:6, on a quarterly basis:
a) total internal debt
b) internal direct debt
c) total external debt
d) direct external debt
e) total public debt
f) effective public debt

2. for the periods 1991:12, 1992:12, and 1993:6-1995:11, on a monthly basis:

a) internal effective direct debt

b) total effective direct debt

3. for the period 1995:7-1998:12, on a monthly basis:

a) internal direct debt

b) total direct debt

4. for the period 1998:12-2008:4, on a monthly basis:

a) direct state debt

Source: Bank of Portugal, the Directorate-General of Treasury, and the DirectorateGeneral of Public Credit.

We build the series for the Direct State Debt as follows:

1) for 1998:12-2008:4, as the series of direct state debt itself;

2) for 1995:7-1997:12, we use the ratio of direct state debt to total state debt in 1998:12 to back-out the series of direct state debt;

3) for 1993:6-1995:6, we use the ratio of total effective direct state debt to total direct state debt in the period 1995:7-1995:11 to get the series of total direct debt;

4) for 1977:12-1993:3, we use the ratio of (effective public debt minus non-direct debt) to total effective direct debt in the period 1993:6-1994:6 to back-out the series of total effective direct debt.

Given that the scale factors are very close to one, the time series of the Direct State Debt is smooth over time and we guarantee that there are not structural breaks. We build the quarterly series using monthly data (where available) and seasonally adjust it using Census X12 ARIMA. The constructed series comprise the period 1977:4-2007:4. 